\title{
И.Г.Петлина, З.А.Залялова
}

\section{О СОЧЕТАНИИ ШИЗОФРЕНИИ С БОЛЕЗНЬЮ ГЕНТИНГТОНА}

\author{
Казанская психиатрическая больница специализированного типа \\ с интенсивным наблюдением МЗ РФ
}

$\Lambda$ анных о сочетании шизофрении с болезнью Гентингтона в доступной нам литературе мы не встретили. Известные авторы (Штернберг, Телле, Тиганов, Снежневский, Жислин, Schrug, Quinn) приводят клиническое описание психопатологической симптоматики при болезни Гентингтона, основным из которой является ослабоумливаюший процесс.

У наблюдаемой нами больной С. неврологическая и патопсихологическая симптоматика была объединена в три нейропсихопатологических синдрома - шизоформный, аффективный и гиперкинетический. Шизоформный синдром включал бредовые идеи колдовства, фрагментарные бредовые идеи отношения и преследования, синдром "положительного двойника". Аффективный синдром был представлен тревожно-депрессивными проявлениями. На фоне диффузной гипотонии выявлялся гиперкинетический синдром в виде дискинезии нижне-лицевой мускулатуры, хореических дистонических гиперкинезов в руках и ногах, в силу которых больная не могла самостоятельно есть и передвигаться.

Со слов больной и из материалов медицинской документации известно, что наследственность отягощена наличием у отца хореатических гиперкинезов. Родилась и росла в семье из восьми детей, в условиях безнадзорности и материальных лишений. В школу пошла с 7 лет. Окснчила 9 классов и курсы продавцов. По специальности проработала 2 года, затем - на хлебозаводе пекарем, на шахте - породовыборшицей. С 1983 г. не работает. Была замужем, разведена. От внебрачной связи имеет сына. С 1983 г. не имела постоянного места жительства, проживала у случайных знакомых, трудоустроиться не пыталась, совершала противоправные действия: в 1990 г. подожгла квартиру сожителя. С 1994 г. проживала вместе с сыном у престарелой гражданки Ш., нуждаюшейся в уходе.

До совершенного преступления (убийство гражданки) на учете у психиатра не состояла. С 1983 г. на фоне социальной дезадаптации (развод с мужем, отсутствие жилья и материальной базы) появились характерологические сдвиги: повышенная раздражительность, эгоцентризм, постоянное недовольство окружающими, а также неглубокие психогенно окрашенные депрессивные состояния. Бродяжничала, нигде не работала, перестала заниматься воспитанием сына. Стала подозрительной, ощущала за собой “слежку”, не пускала ребенка в школу, так как боялась, что сына “убьют племянники мужа". В 1994 г. нанялась в качестве сиделки к престарелой Ш., проживала у нее совместно с сыном, однако с обязанностями сиделки не справлялась, злоупотребляла алкоголем. В состоянии алкогольного опьянения проявляла агрессивность, была неадекватна в поведении, в связи с этим накануне совершенного преступления была выдворена из дома сыном Ш.

11 ноября 1995 г. в состоянии алкогольного опьянения на почве личных неприязненных отношений больная С. совершила убийство Ш., подожгла дом и скрылась. По данному делу была направлена на судебнопсихиатрическую экспертизу, где была беспокойной, совершала беспорядочные движения руками, просила осмотреть ее голову. За внешним видом не следила. Мышление было паралогичное, непоследовательное. Отмечала у себя "путаницу" мыслей, сменяющуюся "пустотой" в голове. Считала, что “ктото читает ее мысли". Чувствовала враждебность окружающих, “злобные взгляды”, слышала шепот за спиной. Испытывала слуховые обманы восприятия: "Голоса говорили, что сына украли контролеры". Считала, что "ero и братьев держат в тюрьме", “хотят уничтожить весь род". При этом становилась возбужденной, требовала освободить сына и братьев из тюрьмы. Была эмоционально неадекватной. О совершенном преступлении рассказала, что ей "было необходимо освободиться" от Ш., так как та была "колдуньей и ведьмой". Поджог дома мотивировала тем, что "он угнетающе действовал" на нее. Психически больной себя не признавала. Не осознавала цели проводимого обследования. Была признана страдаюшей психическим заболеванием: шизофренией, невменяемой 
в отношении содеянного, и направлена на принудительное лечение.

Психическое состояние: при поступлении в больницу у больной уже выявлялись своеобразная неуклюжесть, неловкость и угловатость движений. Была внутренне напряжена, злобна. Оказывала сопротивление при проведении санитарной обработки и врачебных назначений. Нападала на больных и медицинский персонал, угрожала расправой. Плевалась, выбивала дверь, нецензурно бранилась. Мочилась и оправлялась в постели Была сексуально расторможенной, оголялась Воровала продукты у больных. В беседе с врачом высказывала бредовые идеи отношения, преследования: “Мой муж со своими дружками - одна мафия...". Бредовые идеи колдовства были направлены против убитой ею женщины и ее сына: “Старуха колдовала против меня и сына, забирала мысли, делала пустоту в голове... Мы были с сыном, как роботы... Хотели уйти от нее, а не могли". Выявлялся симптом “положительного двойника" в рамках синдрома Капгра: в окружающих людях "узнавала" сына и брата. Требовала их освободить. Во время прогулки подходила к забору и разговаривала с мнимыми родственниками. Настаивала на свидании с ними. Мышление было малопродуктивным, непоследовательным. Психически больной себя не признавала.

Прошла курс лечения: аминазин (75 мг в сут.), пипортил (40 мг в сут.), тизерцин (50 мг в сут.), галоперидол (30 мг в сут.), трифтазин (12 мг в сут.), амизол (40 мг в сут.), амитриптилин (75 мг в сут.), азалептин (150 мг в сут.), реланиум (10 мг в сут.) на фоне корректоров (тропацин, циклодол), а также внутривенные капельные инфузии нейролептиков на физиологическом растворе (состав - 15 мг галоперидола, 100 мг тизерцина, 20 мг реланиума).

В дальнейшем продолжала утверждать, что "видит" на территории больницы своих родственников: “Мужчина в военной форме вел за руку моего сына...". Слышала "голоса" братьев и сына, которые "просили о помощи”. Высказывала бредовые идеи преследования, которые были конгруэнтны по содержанию галлюцинаторным переживаниям: "Сына видела здесь всего окровавленного, избитого бандитами... IШайка украла родственников", а также бредовые идеи колдовства, направленные против убитой ею женщины, ее сыновей и “бывших мужей". Считала, что “сына превратили в женщину Кузнецову Лену”, пыталась опекать больную К., как собственного сына. Мышление было паралогичным, с элементами шпер- рунгов, резонерства. Выявлялись кататонические проявления в виде застываний, эмоциональные нарушения в виде амбивалентности и волевые - в виде амбитендентности. Содержание болезненных переживаний отражалось на поведении больной: становилась крайне возбужденной, злобной, агрессивной. Была навязчивой с требованием свиданий с сыном и братьями, порывалась их "спасти". О содеянном не сожалела. Получала дополнительное лечение: галоперидол (60 мг в сут.), тизерцин (150 мг в сут.), деканоат галоперидола (150 мг один раз в месяц в/м), модитен-депо (50 мг один раз в месяц в/м), мажептил (60 мг в сут.), финлепсин (600 мг в сут).

В дальнейшем неврологическая симптоматика стала нарастать: на фоне обшей слабости появились шаткость походки и дискинезии нижнелицевой мускулатуры, затрудняющие речь. Изначально данная симптоматика была расценена как поздняя дискинезия. В связи с этим биологическая терапия нейролептиками была отменена. Проводились корригируюшая терапия акинетоном и циклодолом, витаминотерапия, форсированный диурез. Регресса неврологической симптоматики не наблюдалось. С февраля 1999 г. редуцировался симптом "положительного двойника", бредовые идеи колдовства стали носить ретроспективный характер, исчезла аффективная заряженность. Однако стало обращать на себя внимание усугубление неврологической симптоматики: появление множественных, постоянных, беспорядочных, некоординированных, насильственных движений конечностями, головой, усиливающиеся при волнении, а также появление “танцующей походки". Выявлялось диффузное снижение мышечного тонуса. Стала нуждаться в дополнительном уходе: ела и передвигалась с помощью персонала. Наблюдалось нарушение речи в виде расстройства произношения, с речевой стереотипией - речевым эмболом. Развивающаяся деменция имела относительно малую прогредиентность и сравнительно небольшую глубину; обнаруживались неустойчивость внимания, повышенная отвлекаемость, непоследовательность мышления, расстройства запоминания и репродуктивной памяти. Выявлялось выраженное эмоциональное притупление с преобладанием благодушного настроения. Стала формально сожалеть о содеянном; “Убивать не надо было. Нужно было просто с сыном от нее уйти".

2 февраля 2000 г. впервые выставляется диагноз: энцефалопатия сложного генеза (дисциркуляторная, посттравматическая , дисметаболическая) в форме прогрессиру- 
ющих хореических гиперкинезов. Находилась под постоянным наблюдением невропатолога и терапевта. Получала специфическое лечение - леводоп, депакин, аминалон, циклодол, но-шпа, финлепсин, нейролептики (малые дозы), антибиотики, витаминотерапия. Однако отмечаемые улучшения носили нестойкий характер с дальнейшей экзацербацией процесса.

6 июня 2000 г. была повторно консультирована невропатологом. Заключение: болезнь Гентингтона (?). Были назначены дополнительные обследования.

УЗИ печени - перипортальные уплотнения в ткани паренхимы с явлениями умеренного гепатоза; утолщение стенок желчного пузыря, наличие конкрементов диаметром 6-8 мм.

Биохимический анализ крови - функциональные печеночные пробы без патологии. C целью дифференциации диагноза с другими заболеваниями, в клинике которых могут встречаться хореические гиперкинезы, была назначена консультация окулиста. Заключение: кольцо Кайзера-Флейшера не определяется. В крови наличие акантоцитов не превышает 15\%. Церулоплазмин крови в норме. Ревматоидные пробы отрицательные. Проведение МРТ головного мозга для обнаружения патогномоничных для болезни Гентингтона признаков (атрофии головки хвостатого ядра) представляется невозможным из-за появления неадекватной реакции больной на предполагаемое исследование: параноидной подозрительности, фобических расстройств (танатофобии) в рамках шизофрении.

В течение последнего года пребывания в стационаре у больной наблюдается приостановка прогредиентности продуктивной симптоматики: инкапсуляция и упрощение бредовых идей. Продолжает усугубляться и нарастать неврологическая симптоматика: генерализация и усиление гиперкинезов не позволяют больной удерживать в руках ложку, самостоятельно есть. Во время сна падает с кровати. Передвигается "танцующей", "скачкообразной" походкой: спотыкается, ушибается об окружаюшие предметы. На фоне прогрессирования хореических гиперкинезов нарастает ослабоумливаюший процесс: обнаруживается усиление мнестических нарушений, с появлением конфабуляций: больная искажает и путает факты своей автобиографии. Утверждает, что "отец убил мать топором, после чего находился в тюрьме", что "работала матросом у мужакапитана в плавании вместе с малолетним сыном". При экспериментально-психологическом исследовании на первый план выступает выраженное снижение мнестических процессов на фоне сужения объема и неустойчивости внимания. Отмечается низкая продуктивность ассоциативных процессов с наличием реакций низшего типа. Уровень обобшения конкретно-функциональный. При проведении нейропсихологических исследований выявляется следующее: сочетание смешанных умеренно выраженных афазий - динамической с акустико-мнестической и моторной. Отмечается неравномерное снижение интеллектуально-мнестических возможностей с недостаточным осмыслением речевого материала: отсутствие отражения ключевых элементов текста, конфабуляторные включения. Выявляется неспособность к пониманию инвертированных конструкций и конструкции родительного падежа. Обнаруживается снижение способности к проведению простых арифметических действий и решению элементарных задач.

Таким образом, у наблюдаемой нами больной с диагнозом шизофрении на фоне наследственной отягощенности (наличие хореических гиперкинезов у отца) в возрасте 45 лет появились и неуклонно прогрессировали хореические гиперкинезы с последующим нарастанием ослабоумливающего процесса. Параклиническими методами были исключены заболевания, в клинике которых могут встречаться аналогичные гиперкинезы: малая хорея, болезнь Вильсона: нейроакантоцитоз. Объективное и лабораторные исследования позволили нам сделать вывод о сочетании шизофрении с болезнью Гентингтона.

Редко встречаюшееся в психиатрической практике сочетание неврологического заболевания (болезни Гентингтона) и эндогенного заболевания (шизофрении) требует особого подхода к лечению данного рода больных. Необходимы соблюдение преемственности в этапности биологической терапии в целом, а также постоянная курация врачами узких специалистей, в первую очередь невропатологом: каузальная терапия больных с таким диагнозом отсутствует.

Данное клиническое наблюдение указывает на формирование интегративного направления в медицине сегодняшнего дня. 